\title{
Dampak pandemi Covid-19 terhadap kepuasan pembelajaran jarak jauh
}

\author{
Rodame Monitorir Napitupulu * \\ Fakultas Ekonomi dan Bisnis Islam, IAIN Padangsidimpuan. \\ Jalan T. Rizal Nurdin km 4.5, Sihitang, Padang Sidempuan, Sumatera Utara 22733, Indonesia. \\ napitupulurm@gmail.com \\ * Corresponding Author
}

\section{ARTICLE INFO}

\section{Article History}

Received:

26 June 2020;

Revised:

7 July 2020;

Accepted:

8 July 2020

\section{Keywords}

Covid-19;

Pembelajaran jarak

jauh;

Kepuasan;

Teknologi;

Distance learning;

Satisfaction;

Technology

\begin{abstract}
Pandemi Covid-19 saat ini berdampak pada perguruan tinggi. IAIN Padangsidimpuan sebagai salah satu institusi pendidikan tinggi negeri keagamaan Islam di Indonesia dituntut untuk mengikuti perubahan metode pembelajaran yaitu pembelajaran jarak jauh (PJJ) yang semula sepenuhnya dilakukan dengan tatap muka. Letak kampus yang berada di Bagian Selatan Sumatera Utara dengan asal mahasiswa yang beragam dan berada jauh dari perkotaan menjadi tantangan tersendiri bagi institusi. Penelitian ini menggunakan pendekatan kualitatif dengan analisis deskriptif. Jumlah informan 384 orang yang terdiri dari mahasiswa aktif Fakultas Ekonomi dan Bisnis Islam IAIN Padangsidimpuan yang dipilih secara acak. Berdasarkan hasil penelitian diketahui bahwa, meskipun mayoritas mahasiswa $(95,8 \%)$ sudah memiliki perangkat untuk menjalani PJJ, namun di sisi lain mahasiswa merasa metode PJJ saat ini belum tepat karena mahasiswa merasa tidak dapat memantau perkembangan PJJ dengan mudah, tidak dapat memperoleh materi pembelajaran dengan mudah juga tidak dapat mempelajari materi dengan mudah. Secara keseluruhan, baik dari sisi teknologi maupun sisi dosen, mahasiswa tidak puas dengan metode PJJ yang dijalaninya saat ini dan juga merasa tidak puas dengan kemampuan dosen dalam menyampaikan materi pada PJJ.
\end{abstract}

The Covid19 pandemic is currently affecting universities. IAIN Padangsidimpuan as one of the institutions of Islamic religious state higher education in Indonesia is required to follow the changes in learning methods, namely distance learning (PJJ), which is from the beginning is fully face-to-face. The location of the campus in the Southern Part of North Sumatra with diverse origins of students and being far from urban areas is a challenge for institutions. This research uses a qualitative approach with descriptive analysis. The number of informants 384 people consisting of active students of the Faculty of Islamic Economics and Business were randomly selected. Based on the results of the study note that, although the majority of students (95.8\%) already have the tools to undergo Distance Learning, on the other hand students feel the distance learning method is currently not appropriate because students feel unable to monitor the development of distance learning easily, cannot obtain learning material easily nor can study material easily. Overall, both in terms of technology and the Lecturer side, students are not satisfied with the distance learning method they are currently undergoing and also feel dissatisfied with the ability of the Lecturer to deliver material to distance learning.

This is an open access article under the CC-BY-SA license.

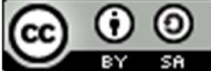




\section{PENDAHULUAN}

Pandemi Covid-19 yang saat ini masih terus berlangsung membawa perubahan pada metode pembelajaran jarak jauh (PJJ). Berdasarkan data yang diperoleh, per 18 Juni 2020, jumlah terpapar Covid-19 di Indonesia mencapai 42.762 meningkat 1.331 (Satuan Tugas Penanganan Covid-19, 2020). Sementara itu, di Sumatera Utara sendiri yang terpapar Covid-19 telah mencapai 993 (Satuan Tugas Penanganan Covid-19, 2020). Peningkatan jumlah yang terpapar Covid-19 ini menjadi perhatian untuk semua pihak termasuk berbagai kementerian yang membawahi perguruan tinggi di Indonesia. Berbagai perguruan tinggi yang berada di zona merah, orange dan kuning tidak lagi diperbolehkan melakukan perkuliahan tatap muka (pengumuman resmi dari Kementerian Pendidikan dan Kebudayaan Republik Indonesia: 94\% siswa belajar dari rumah, 6\% di Zona Hijau boleh tatap muka, n.d.).

Perguruan tinggi yang tadinya sepenuhnya melakukan metode tatap muka (face-to-face) saat perkuliahan maupun bimbingan skripsi dan kegiatan akademik lainnya kini perlu mengubahnya menjadi metode PJJ. Dalam istilah asingnya disebut dengan distance learning. Dalam berbagai penelitian lainnya juga dikenal dengan online learning, e-learning (electronic learning) maupun daring (dalam jaringan). Kini menjadi tantangan bagi dosen, mahasiswa yang mau tidak mau harus siap menghadapi online learning yang ada (Tîrziu \& Vrabie, 2015). Perbedaan pembelajaran tatap muka (face-to-face) dengan PJJ memberikan pengaruh berbeda terhadap mutu belajar mahasiswa (Karwati, 2014).

Bagi perguruan tinggi yang lokasinya di wilayah geografis yang lemah koneksi internetnya dan belum tersentuh listrik maka ini menjadi tantangan tersendiri. Institut Agama Islam Negeri (IAIN) Padangsidimpuan adalah salah satu perguruan tinggi keagamaan Islam negeri (PTKIN) di bawah naungan Kementerian Agama yang turut menyepakati putusan resmi terkait pelaksanaan PJJ. IAIN Padangsidimpuan dengan 4 fakultas yang mahasiswanya menyebar di berbagai wilayah termasuk wilayah yang tidak memadai koneksi internetnya akan menjadi kewalahan dengan model PJJ ini. Salah satu fakultas dengan jumlah mahasiswa tertinggi adalah Fakultas Ekonomi dan Bisnis Islam. Dampak Covid-19 ini juga memengaruhi proses pembelajaran mahasiswa saat ini. Setidaknya pada PJJ terdapat tiga unsur penting yang mendukung kesusksesannya ketika diterapkan oleh perguruan tinggi, yaitu: mahasiswa, dosen, teknologi (Tîrziu \& Vrabie, 2015).

Salah satu misi dari IAIN Padangsidimpuan adalah menyelenggarakan pendidikan dan pengajaran ilmu-ilmu keislaman, ilmu-ilmu sosial dan humaniora yang integratif dan unggul (visi dan misi IAIN Padangsidimpuan, n.d.). Dalam misi tersebut tentu tersirat penyelenggaraan pendidikan yang terbaik dalam rangka mencapai visi. Fakultas Ekonomi dan Bisnis Islam sendiri memiliki misi untuk menjadikan Fakultas Ekonomi dan Bisnis Islam centre of excellence untuk menghasilkan lulusan yang profesional, entrepreneuship dan berakhlak mulia di Indonesia tahun 2025. Tentu saja dalam upaya pencapaian visi tersebut, fakultas harus berbenah dan meningkatkan proses PJJ guna memberikan layanan pendidikan terbaik. Terbaik dalam arti dapat memuaskan mahasiswa sebagai calon SDM berkualitas yang menjadi tolok ukur keberhasilan sebuah institusi pendidikan di perguruan tinggi. Banyak faktor yang memengaruhi kepuasan PJJ diantaranya: teknologi, konten edukasi, motivasi dan sikap (Navimipour \& Zareie, 2015), tingkat kesiapan mahasiswa (Yilmaz, 2017), kesesuaian informasi dengan kebutuhan (Isaac et al., 2019), desain pembelajaran (Rienties \& Toetenel, 2016), kualitas informasi (Pereira, Ramos, Gouvêa, \& da Costa, 2015), pengalaman (Deshwal, Trivedi, \& Himenshi, 2017). Jika mahasiswa memperoleh kepuasan pembelajaran online maka akan berpengaruh terhadap motivasi dan hasil pembelajaran (Wang, Hsu, Bonem, Moss, Yu, Nelson, \& Levesque-Bristol, 2019; Kurucay \& Inan, 2017), nilai yang dipersepsikan dan intensitas keberlanjutan (Nugroho, Setyorini, \& Novitasari, 2019).

Kepuasan mahasiswa dalam menjalani PJJ ini menjadi masukan penting dalam rangka perbaikan di masa yang mendatang. Peranan literasi teknologi informasi dan komunikasi penting dalam PJJ di masa pandemi Covid-19 ini (Latip, 2020). Terutama jika pandemi Covid-19 masih terjadi maka PJJ akan terus dipilih sebagai metode paling aman terutama di Kota Padangsidimpuan dimana lokasi perguruan tinggi berada yang sampai saat ini berada pada zona kuning. Penelitian ini dapat berkontribusi dalam memberikan masukan terkait pelaksanaan PJJ saat ini. Oleh karena itu, 
tujuan penelitian ini adalah untuk mengetahui dampak pandemic Covid-19 terhadap kepuasan pembelajaran jarak jauh.

\section{METODE}

Penelitian ini merupakan penelitian cross-sectional dengan pendekatan kualitiatif deskriptif. Informan dalam penelitian ini adalah mahasiswa Fakultas Ekonomi dan Bisnis Islam IAIN Padangsidimpuan. Informan adalah mahasiswa aktif yang menjalani PJJ. Informan dipilih secara acak, dari berbagai semester dan program studi. Jumlah informan pada penelitian ini adalah 384 orang. Metode pengumpulan data dilakukan dengan penyebaran kuesioner elektronik (equestionnaire). Penyebaran kuesioner elektronik dilakukan melalui media sosial Whatsapp pada grup-grup kelas di FEBI. Penyebaran hingga terkumpulnya data primer berlangsung dalam kurun waktu kurang lebih 1 bulan selama masa pandemi Covid-19 di Indonesia khususnya Kota Padangsidimpuan dan sekitarnya. Kuesioner elektronik dibuat dalam bentuk pertanyaan dengan pilihan yang tersedia (closed-ended questions). Setelah data terkumpul, lalu dianalisis secara deskriptif dengan mentabulasikan persentase pada masing-masing pertanyaan yang dijawab secara lengkap oleh informan. Selanjutnya dibahas dengan studi kepustakaan.

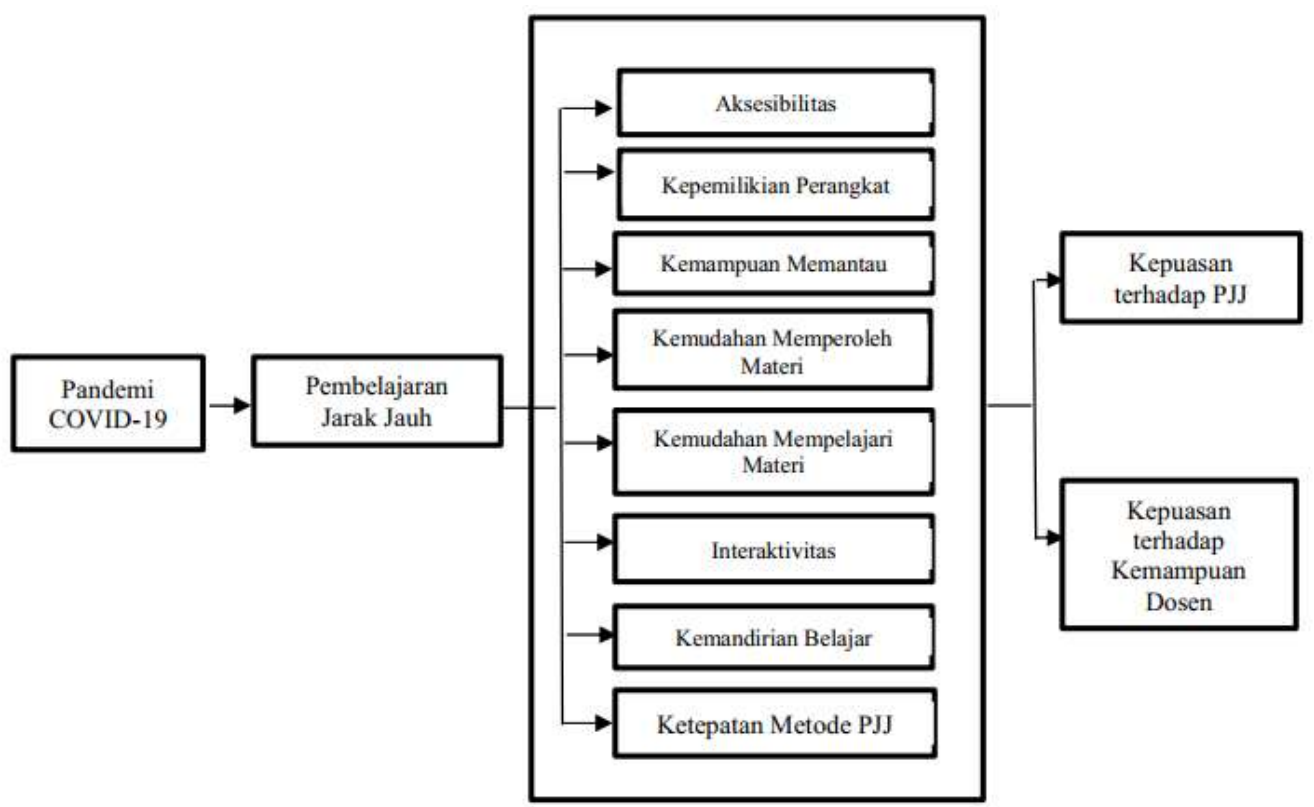

Gambar 1.Kerangka Konseptual Penelitian

\section{HASIL DAN PEMBAHASAN}

Penelitian ini menghasilkan poin-poin penting terkait dampak pandemi Covid-19 terhadap kepuasan PJJ pada mahasiswa khususnya mahasiswa Fakultas Ekonomi dan Bisnis Islam IAIN Padangsidimpuan. Hasil penelitian dipaparkan mulai dari karakteristik informan hingga pembahasan berdasarkan literatur yang relevan dengan berbagai aspek yang diteliti. Selengkapnya adalah sebagai berikut.

\section{Karakteristik Informan}

Penyebaran kuesioner elektronik (e-questionnaire) penelitian dilaksanakan dalam kurun waktu 1 bulan. Hasil penyebarannya mengumpulkan sebanyak 384 informan. Informan penelitian yaitu mahasiswa Fakultas Ekonomi dan Bisnis Islam IAIN Padangsidimpuan dengan karakteristik 
beragam pada jenis kelamin, program studi, semester, lokasi tempat tinggal dan media pembelajaran jarak jauh (PJJ) yang digunakan saat penelitian berlangsung. Selengkapnya dapat dilihat pada Tabel 1.

Table 1. Karakteristik Informan

\begin{tabular}{|c|c|c|c|}
\hline Karakteristik Informan & & Frekuensi & Persentase \\
\hline \multirow{3}{*}{ Jenis Kelamin } & Perempuan & 299 & $77,9 \%$ \\
\hline & Laki-Laki & 85 & $21,1 \%$ \\
\hline & Total & 384 & $100 \%$ \\
\hline \multirow{4}{*}{ Program Studi } & Perbankan Syariah & 222 & $57,8 \%$ \\
\hline & Ekonomi Syariah & 149 & $38,8 \%$ \\
\hline & Manajemen Zakat dan Wakaf & 13 & $3,4 \%$ \\
\hline & Total & 384 & $100 \%$ \\
\hline \multirow{5}{*}{ Semester } & 2 & 29 & $7,6 \%$ \\
\hline & 4 & 265 & $69 \%$ \\
\hline & 6 & 79 & $19,3 \%$ \\
\hline & 8 & 16 & $4,2 \%$ \\
\hline & Total & 384 & $100 \%$ \\
\hline \multirow{4}{*}{$\begin{array}{l}\text { Lokasi Tempat Tinggal } \\
\text { Saat Pandemi Covid-19 }\end{array}$} & Kota Padangsidimpuan & 147 & $38,3 \%$ \\
\hline & Kabupaten Tapanuli Selatan & 149 & $38,8 \%$ \\
\hline & Bukan Keduanya & 88 & $22,9 \%$ \\
\hline & Total & 384 & $100 \%$ \\
\hline \multirow{5}{*}{$\begin{array}{l}\text { Media Pembelajaran } \\
\text { Jarak Jauh (PJJ) yang } \\
\text { diikuti saat ini }\end{array}$} & Aplikasi Meeting (Zoom, Google Meet, Google & 108 & $28,1 \%$ \\
\hline & Classroom, dll.) & & \\
\hline & Media Sosial (Whatsapp, Instagram, Facebook, dll.) & 17 & $4,4 \%$ \\
\hline & Keduanya & 259 & $67,4 \%$ \\
\hline & Total & 384 & $100 \%$ \\
\hline
\end{tabular}

Faktor-Faktor yang Mempengaruhi Kepuasan Pembelajaran Jarak Jauh (PJJ)

\section{Aksesibilitas}

Faktor pertama yang memengaruhi kepuasan PJJ adalah aksesibilitas. Berdasarkan hasil penelitian dapat dilihat bahwa mayoritas informan menjawab netral terhadap pertanyaan tersebut. Sementara itu, 31,8\% menjawab setuju yang artinya informan memiliki akses terhadap PJJ melalui koneksi internet. Namun, masih ada sekitar 12 orang atau 3,1\% dan 7 orang atau $1,8 \%$ informan yang tidak memiliki akses terhadap teknologi PJJ. Hal tersebut sejalan dengan hasil penelitian terdahulu yang menyatakan bahwa akses terhadap teknologi berperan penting dalam PJJ (Liu, Geertshuis, \& Grainger, 2020; Farhan, Razmak, Demers, \& Laflamme, 2019; Shen \& Ho, 2020; Seale \& Cooper, 2010; Amado-Salvatierra, Hernández, \& Hilera, 2012).

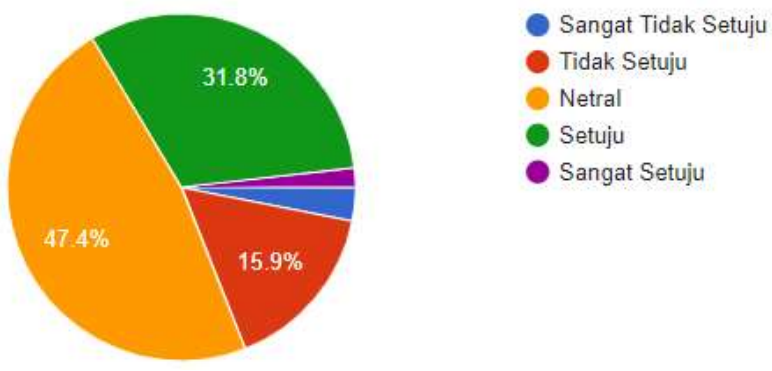

Gambar 2. Aksesibilitas terhadap Teknologi PJJ 


\section{Kepemilikan Perangkat}

Terkait dengan faktor kedua yaitu kepemilikan perangkat. Berdasarkan hasil penelitian, diketahui bahwa mayoritas informan memiliki perangkat untuk melakukan PJJ. Meskipun begitu, masih terdapat 4,2\% yang tidak memiliki perangkat untuk melakukan PJJ. Hal ini didukung oleh beberapa hasil penelitian yang menyebutkan bahwa tools atau perangkat berperan dalam proses pembelajaran.(Jurkovič, 2019; Kim \& Park, 2019).

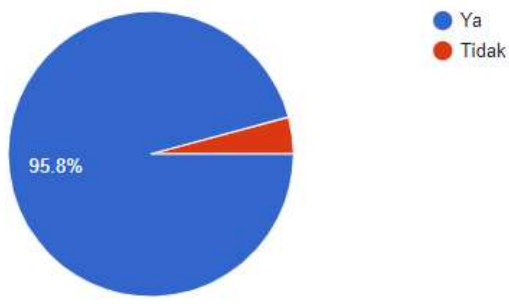

Gambar 3. Kepemilikan Perangkat untuk PJJ

\section{Kemampuan Memantau}

Kemampuan memantau perkembangan pembelajaran jarak jauh setiap saat dengan mudah menjadi salah satu faktor yang memengaruhi kepuasan mahasiswa. Berdasarkan hasil penelitian dapat dilihat bahwa, mayoritas informan tidak memiliki kemampuan dalam memantau perkembangan PJJ setiap saat dengan mudah. Dimana sebanyak 65,9\% menyatakan tidak dapat memantau perkembangan PJJ setiap saat dengan mudah. Sisanya sebanyak 34, 1\% menyatakan dapat memantau perkembangan PJJ setiap saat dengan mudah. Kesulitan dalam memantau perkembangan materi PJJ dapat disebabkan karena sulitnya mengakses informasi melalui metode PJJ yang digunakan saat ini juga ketersediaan koneksi internet.

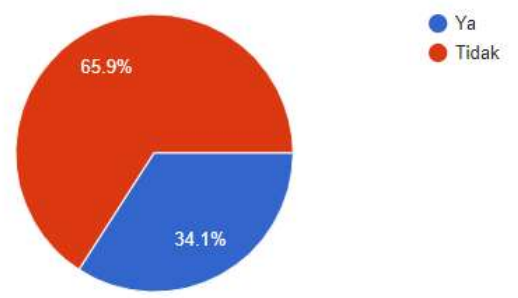

Gambar 4. Kemampuan Memantau

\section{Kemudahan Memperoleh Materi}

Faktor keempat yang turut memengaruhi kepuasan mahasiswa dalam pembelajaran jarak jauh adalah kemudahan untuk memperoleh materi pembelajaran dengan mudah. Berdasarkan hasil penelitian dapat diketahui bahwa mayoritas informan merasa kesulitan dalam memperoleh materi PJJ. Dimana sebanyak 65,6 \% informan menjawab tidak mudah dalam memperoleh materi pembelajaran. Sisanya sebanyak 34,4 \% merespon sebaliknya. Hal ini tidak sejalan dengan hasil penelitian yang menyatakan bahwa kemudahan akses terhadap materi yang diberikan dosen berperan penting dalam perkuliahan (Restrepo, Benavidez, \& Gutiérrez, 2012).

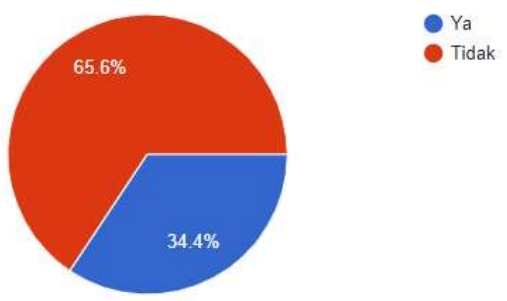

Gambar 5. Kemudahan Memperoleh Materi 


\section{Kemudahan Memperlajari Materi}

Kemudahan mempelajari materi pembelajaran menjadi salah satu faktor yang juga memengaruhi kepuasan mahasiswa dalam PJJ. Hasil penelitian menunjukkan bahwa mayoritas merasa kesulitan dalam mempelajari materi pembelajaran yang diberikan secara daring. Dari 384 orang mahasiswa, sebanyak 83,6 \% menjawab tidak mudah mempelajari materi PJJ. Hanya sebanyak 16,4 $\%$ yang menjawab dapat dengan mudah mempelajari materi PJJ.

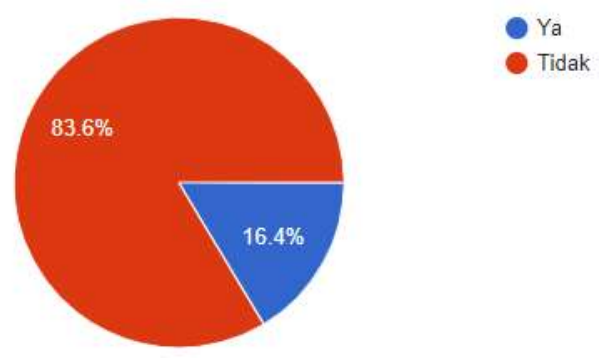

Gambar 6. Kemudahan Mempelajari Materi

\section{Interaktivitas}

Faktor keberhasilan PJJ lainnya dari sisi kualitas sistem pendidikan adalah interaktivitas. Berdasarkan hasil penelitian, mayoritas merasa mudah dan mampu dalam berinteraksi dengan Dosen. Informan mampu bertanya dan memberi respon terhadap materi pembelajaran yang diberikan oleh Dosen. Namun, terdapat 25,3 \% masih merasa sulit berinteraksi dimana mahasiswa masih sulit bertanya dan memberi respon terhadap materi pembelajaran yang diberi Dosen. Hal ini sejalan dengan hasil penelitian yang menyatakan bahwa interaktif dan adanya kesempatan merespon materi saat PJJ berperan penting (Nylund \& Lanz, 2020). Interaktivitas merupakan unsur yang harus ada pada PJJ (Tîrziu \& Vrabie, 2015).

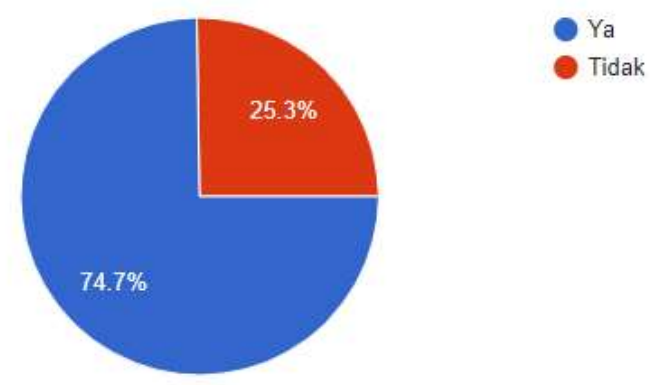

Gambar 7. Interaktivitas

\section{Ketepatan Metode}

Metode pembelajaran jarak jauh yang tepat dapat membantu efektivitas proses PJJ tersebut. Efektivitas metode PJJ memengaruhi kepuasan mahasiswa. Hasil penelitian memberikan respon yang beragam. Mayoritas informan menjawab tidak setuju, yang artinya metode PJJ yang saat ini digunakan masih belum tepat. Dari total 384 orang informan, hanya 4 orang informan yang menjawab sangat setuju, 40 orang informan menjawab setuju dengan pemilihan metode PJJ saat ini. Untuk diketahui bersama saat ini di IAIN Padangsidimpuan khususnya FEBI, sudah menggunakan berbagai media dalam PJJ diantaranya aplikasi meeting online (Zoom, Google Meet, Google Classroom) dan media sosial (Whatsapp, Facebook, Instagram). Metode PJJ yang tepat juga berpengaruh pada kualitas sistem dan kualitas informasi dan kualitas layanan yang diterima oleh mahasiswa (Pawirosumarto, 2016). Selain itu, metode yang tepat juga dapat berpengaruh pada sikap 
mahasiswa dalam menjalaninya (Aziz, 2013). Berdasarkan jawaban informan, saat ini metode yang dijalani dalam PJJ belum tepat.

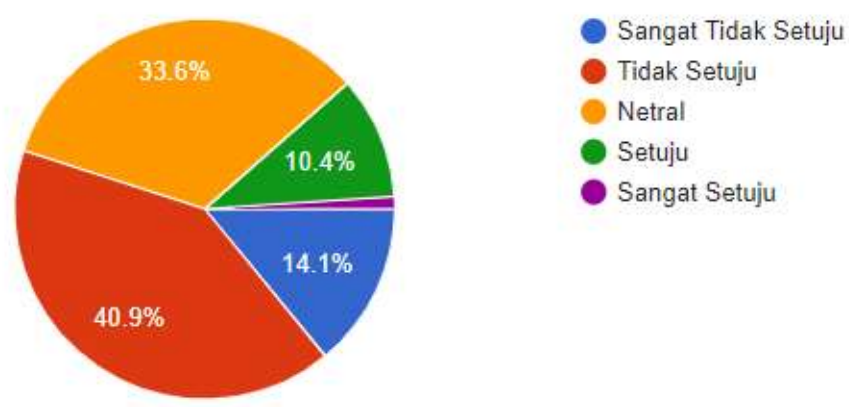

Gambar 8. Ketepatan Metode

\section{Kemandirian Belajar}

Kepuasan mahasiswa dalam menjalankan pembelajaran jarak jauh juga dipengaruhi oleh adanya kemampuan mahasiswa dalam belajar secara mandiri. Berdasarkan hasil penelitian, diketahui bahwa terdapat sebanyak 103 orang informan atau 27,9\% mahasiswa merasa bahwa PJJ saat ini tidak membuatnya mampu belajar secara mandiri. Secara teoritis, kemandirian belajar adalah faktor penentu keberhasilan PJJ. Namun, baru sebagian mahasiswa yang telah memiliki kemandirian belajar belum sepenuhnya berhasil dirasakan oleh seluruh mahasiswa. Hanya sebanyak $27,9 \%$ yang menjawab setuju akan dampak PJJ pada kemandirian belajar. Hal ini mungkin disebabkan karena mahasiswa di FEBI belum terbiasa dengan metode PJJ yang dijalani saat ini. Terjadinya Covid-19 memaksa mahasiswa menjalani PJJ dengan kemandirian yang belum sepenuhnya ada pada tiap mahasiswa. Proses pembelajaran tatap muka yang selama ini dilakukan kurang berdampak pada kemandirian mahasiswa dalam belajar, setidaknya masih ada mahasiswa yang merasa semakin mandiri belajar setelah menjalani PJJ.

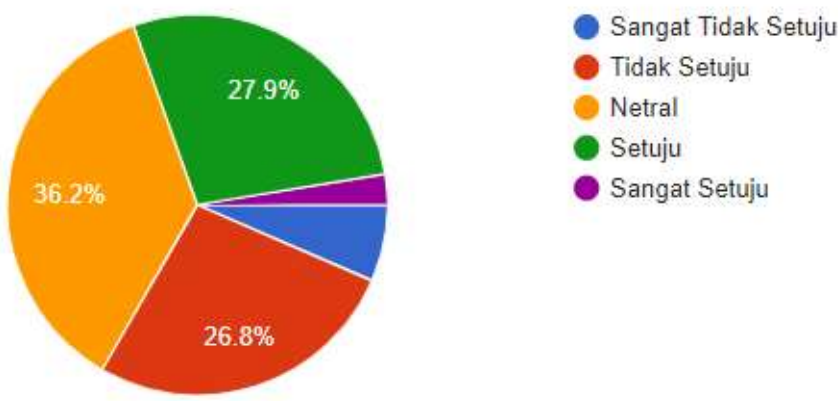

Gambar 9. Kemandirian Belajar

\section{Kepuasan terhadap PJJ}

Secara keseluruhan, terkait dengan kepuasan mahasiswa dalam pembelajaran jarak jauh sebagai akibat dari terjadinya pandemi Covid-19 ini dibedakan pada dua sisi. Sisi teknologi dan sisi dosen. Berdasarkan hasil penelitian, dapat diketahui bahwa mayoritas merasa tidak puas terhadap pembelajaran jarak jauh saat ini. Dampak Covid-19 ternyata memberikan ketidakpuasan pada mahasiswa dalam menerima materi pembelajaran. Hal ini mungkin saja terjadi karena berbagai alasan. Alasan paling utama adalah karena selama ini mahasiswa memang menerima pembelajaran face-to-face, sehingga mungkin ada ketidaksiapan dalam menggunakan berbagai metode PJJ (Yilmaz, 2017). 


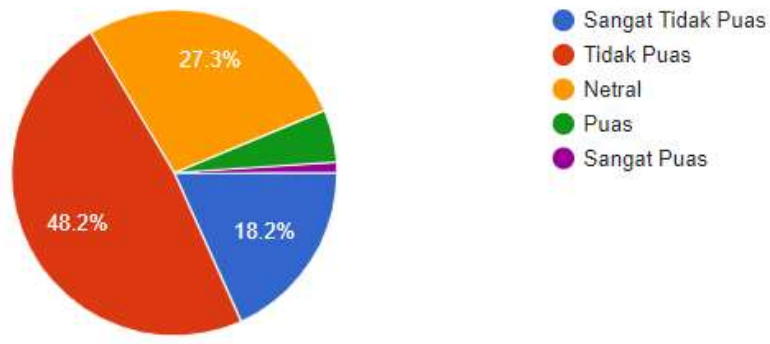

Gambar 10. Tingkat Kepuasan terhadap PJJ

Terbukti dari hasil penelitian hanya 4 orang informan yang merasa sangat puas dengan PJJ yang berlangsung saat ini. Sementara itu, faktor lainnya yang berpengaruh pada kepuasan mahasiswa menjalani PJJ adalah kelas dosen, konten, penilaian dan jadwal (Hew, $\mathrm{Hu}$, Qiao, \& Tang, 2020). Selain konten, pendekatan pembelajaran yang terintegrasi dengan bahasa juga memengaruhi kepuasan mahasiswa dalam mengikuti PJJ (Granel, Leyva-Moral, Bernabeu-Tamayo, Gómez-Ibáñez, Watson, \& Aguayo-González, 2019). Kualitas informasi dan kualitas sistem juga menjadi kunci kesuksesan PJJ (Cidral, Oliveira, Di Felice, \& Aparico, 2018).

\section{Tingkat Kepuasan terhadap Kemampuan Dosen}

Secara keseluruhan, informan menilai tidak memuaskan dimana mayoritas mahasiswa menilai bahwa dosen belum mampu menyampaikan materi pada PJJ saat ini. Sebanyak 161 informan menjawab tidak puas. Hanya 40 orang yang merasa puas dengan kemampuan dosen dalam menyampaikan materi PJJ. Ketidakpuasan dari sisi dosen dirasakan oleh mahasiswa pada PJJ saat ini. Kemampuan intelektual, pembelajaran individu dan kemampuan internal of locus of control seharusnya ada pada setiap dosen (Rachman, 2012). Kemampuan dosen terlibat aktif dan memberikan tambahan ilmu secara online berpengaruh dalam meningkatkan mutu pembelajaran (Karwati, 2014). Selain itu, Sikap Dosen saat PJJ berpengaruh pada kepuasan mahasiswa (Cidral, Oliveira, Di Felice, \& Aparico, 2018). Kepercayaan diri dalam menggunakan teknologi terhadap pembelajaran baru juga berpengaruh terhadap kualitas dosen (Tîrziu \& Vrabie, 2015). Penyampaian materi secara face-to-face tentu berbeda dengan penyampaian materi melalui PJJ.

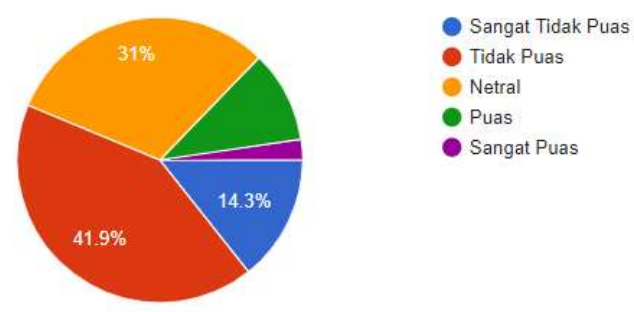

Gambar 11. Tingkat Kepuasan terhadap Kemampuan Dosen

\section{SIMPULAN}

Pandemi Covid-19 saat ini memang berdampak pada banyak hal termasuk pada dunia pendidikan yaitu perguruan tinggi. IAIN Padangsidimpuan sebagai salah satu institusi pendidikan tinggi negeri keagamaan Islam di Indonesia dituntut untuk mengikuti perubahan metode pembelajaran sebagai dampak dari pandemi Covid-19 ini. Letak kampus yang berada di Bagian Selatan Sumatera Utara dengan asal mahasiswa yang beragam dan berada jauh dari perkotaan menjadi tantangan tersendiri bagi institusi. Meskipun mayoritas mahasiswa $(95,8 \%)$ sudah memiliki 
perangkat untuk menjalani PJJ, namun di sisi lain mahasiswa merasa metode PJJ saat ini belum tepat karena mahasiswa merasa tidak dapat memantau perkembangan PJJ dengan mudah, tidak dapat memperoleh materi pembelajaran dengan mudah juga tidak dapat mempelajari materi dengan mudah. Berdasarkan hasil penelitian, diketahui bahwa secara keseluruhan baik dari sisi teknologi maupun sisi dosen, mahasiswa merasa tidak puas. Mahasiswa tidak puas dengan metode PJJ yang dijalaninya saat ini dan juga merasa tidak puas dengan kemampuan Dosen dalam menyampaikan materi pada PJJ. Berdasarkan hasil penelitian tersebut, maka perguruan tinggi perlu meninjau kembali metode PJJ yang ada saat ini. Selain itu juga perlu memperkuat kemampuan literasi digital baik mahasiswa maupun dosen.

\section{DAFTAR PUSTAKA}

Amado-Salvatierra, H. R., Hernández, R., \& Hilera, J. R. (2012). Implementation of accessibility standards in the process of course design in virtual learning environments. Procedia Computer Science, 14, 363-370. doi:https://doi.org/10.1016/j.procs.2012.10.042

Aziz, A. L. (2013). Pengaruh kemudahan penggunaan terhadap kemanfaatan pada sikap pengguna e-learning survei pada mahasiswa jurusan Administrasi Bisnis, Fakultas Ilmu Administrasi Universitas Brawijaya Malang Angkatan 2011. Jurnal Administrasi Bisnis, 6(2), 1-7.

Cidral, W. A., Oliveira, T., Di Felice, M., \& Aparicio, M. (2018). E-learning success determinants: Brazilian empirical study. Computers \& Education, 122, 273-290. doi:https://doi.org/10.1016/j.compedu.2017.12.001

Deshwal, P., Trivedi, A., \& Himanshi, H. L. N. (2017). Online learning experience scale validation and its impact on learners' satisfaction. Procedia computer science, 112, 2455-2462. doi:https://doi.org/10.1016/j.procs.2017.08.178

Farhan, W., Razmak, J., Demers, S., \& Laflamme, S. (2019). E-learning systems versus instructional communication tools: Developing and testing a new e-learning user interface from the perspectives of teachers and students. Technology in Society, 59, 101192. doi:https://doi.org/10.1016/j.techsoc.2019.101192

Granel, N., Leyva-Moral, J. M., Bernabeu-Tamayo, M. D., Gómez-Ibáñez, R., Watson, C. E., \& Aguayo-González, M. P. (2019). Student satisfaction with content and language integrated learning in nursing education: A cross-sectional study. Nurse Education in Practice, 38, $21-$ 26. doi:https://doi.org/10.1016/j.nepr.2019.05.011

Hew, K. F., Hu, X., Qiao, C., \& Tang, Y. (2020). What predicts student satisfaction with MOOCs: A gradient boosting trees supervised machine learning and sentiment analysis approach. Computers \& Education, 145, 103724. doi:https://doi.org/10.1016/j.compedu.2019.103724

Isaac, O., Aldholay, A., Abdullah, Z., \& Ramayah, T. (2019). Online learning usage within Yemeni higher education: The role of compatibility and task-technology fit as mediating variables in the IS success model. Computers \& Education, 136, 113-129. doi:https://doi.org/10.1016/j.compedu.2019.02.012

Navimipour, N. J., \& Zareie, B. (2015). A model for assessing the impact of e-learning systems on employees' satisfaction. Computers in Human Behavior, 53, 475-485. doi: https://doi.org/10.1016/j.chb.2015.07.026

Jurkovič, V. (2019). Online informal learning of English through smartphones in Slovenia. System, 80, 27-37. doi:https://doi.org/10.1016/j.system.2018.10.007

Karwati, E. (2014). Pengaruh Pembelajaran elektronik (e-learning) terhadap mutu belajar mahasiswa. Jurnal Penelitian Komunikasi, 17(1), 41-54.

Kim, J. H., \& Park, H. (2019). Effects of smartphone-based mobile learning in nursing education: A systematic review and meta-analysis. Asian Nursing Research, 13(1), 20-29. doi:https://doi.org/10.1016/j.anr.2019.01.005 
Kurucay, M., \& Inan, F. A. (2017). Examining the effects of learner-learner interactions on satisfaction and learning in an online undergraduate course. Computers \& Education, 115, 20-37. doi:https://doi.org/10.1016/j.compedu.2017.06.010

Latip, A. (2020). Peran literasi teknologi informasi dan komunikasi pada pembelajaran jarak jauh di masa pandemi Covid-19. EduTeach: Jurnal Edukasi dan Teknologi Pembelajaran, 1(2), 108-116. doi:https://doi.org/10.37859/eduteach.v1i2.1956

Liu, Q., Geertshuis, S., \& Grainger, R. (2020). Understanding academics' adoption of learning technologies: A systematic review. Computers \& Education, 151, 103857. doi:https://doi.org/10.1016/j.compedu.2020.103857

Nugroho, M. A., Setyorini, D., \& Novitasari, B. T. (2019). The role of satisfaction on perceived value and e-learning usage continuity relationship. Procedia Computer Science, 161, 82-89. doi:https://doi.org/10.1016/j.procs.2019.11.102

Nylund, H., \& Lanz, M. (2020). Interactive learning activities for education of factory level orderto-delivery process. Procedia Manufacturing, 45, 504-509. doi:https://doi.org/10.1016/j.promfg.2020.04.065

Pawirosumarto, S. (2016). Pengaruh kualitas sistem, kualitas informasi, dan kualitas layanan terhadap kepuasan pengguna sistem e-learning. MIX: Jurnal Ilmiah Manajemen, 6(3), 152864 .

PENGUMUMAN RESMI Dari Mendikbud: 94\% Siswa Belajar dari Rumah, 6\% di Zona Hijau Boleh Tatap Muka. (2020, Juni 15). Liputan9. Retrieved from http://www.belajardirumah.org/2020/06/bundaterbaru-dari-mendikbud-94-siswa.html

Pereira, F. A. de M., Ramos, A. S. M., Gouvêa, M. A., \& da Costa, M. F. (2015). Satisfaction and continuous use intention of e-learning service in Brazilian public organizations. Computers in Human Behavior, 46, 139-148. doi:https://doi.org/10.1016/j.chb.2015.01.016

Rachman, M. M. (2012). Pengaruh kemampuan intelektual, pembelajaran individual dan internal locus of control terhadap kompetensi dan kinerja dosen (Studi Prodi Manajemen Terakreditasi B pada Universitas Swasta di Surabaya). Jurnal Ekonomi dan Bisnis Airlangga (JEBA), 22(1), 91-105.

Restrepo, E. G. y, Benavidez, C., \& Gutiérrez, H. (2012). The challenge of teaching to create accessible learning objects to higher education lecturers. Procedia Computer Science, 14, 371-381. doi:https://doi.org/10.1016/j.procs.2012.10.043

Rienties, B., \& Toetenel, L. (2016). The impact of learning design on student behaviour, satisfaction and performance: A cross-institutional comparison across 151 modules. Computers in Human Behavior, 60, 333-341. doi:https://doi.org/10.1016/j.chb.2016.02.074

Satuan Tugas Penanganan Covid-19. (2020). Infografis COVID-19 (18 Juni 2020). Retrieved from https://covid19.go.id/p/berita/infografis-covid-19-18-juni-2020

Seale, J., \& Cooper, M. (2010). E-learning and accessibility: An exploration of the potential role of generic pedagogical tools. Computers \& Education, 54(4), 1107-1116. doi:https://doi.org/10.1016/j.compedu.2009.10.017

Shen, C., \& Ho, J. (2020). Technology-enhanced learning in higher education: A bibliometric analysis with latent semantic approach. Computers in Human Behavior, 104, 106177. doi:https://doi.org/10.1016/j.chb.2019.106177

Tîrziu, A. M., \& Vrabie, C. (2015). Education 2.0: E-learning methods. Procedia-Social and Behavioral Sciences, 186, 376-380. doi:https://doi.org/10.1016/j.sbspro.2015.04.213

Wang, C., Hsu, H.-C. K., Bonem, E. M., Moss, J. D., Yu, S., Nelson, D. B., \& Levesque-Bristol, C. (2019). Need satisfaction and need dissatisfaction: A comparative study of online and face- 
to-face learning contexts. Computers in Human Behavior, 95, 114-125. doi:https://doi.org/10.1016/j.chb.2019.01.034

Yilmaz, R. (2017). Exploring the role of e-learning readiness on student satisfaction and motivation in flipped classroom. Computers in Human Behavior, 70, 251-260. doi:https://doi.org/10.1016/j.chb.2016.12.085 